\title{
The Effect of Non Performing Financing (NPF) and Earning Asset Quality (KAP) on Return On Assets (ROA) at PT. Bank Rakyat Indonesia Syariah, Tbk 2009-2018
}

\author{
Nurhaliza ${ }^{1}$, Nofinawati ${ }^{2}$, Damri Batubara ${ }^{3}$, Nando Fahrizal ${ }^{4}$ \\ ${ }^{1}$ IAIN Padangsidimpuan (Perbankan Syariah, FEBI, IAIN Padangsidimpuan) \\ ${ }^{2}$ IAIN Padangsidimpuan (Perbankan Syariah, FEBI, IAIN Padangsidimpuan) \\ ${ }^{3}$ IAIN Padangsidimpuan (Ekonomi Syariah, FEBI, IAIN Padangsidimpuan) \\ ${ }^{4}$ IAIN Padangsidimpuan (Perbankan Syariah, FEBI, IAIN Padangsidimpuan) \\ nurhaliza@gmail.com ${ }^{1}$, nofinawati@iain-padangsidimpuan.ac.id, damri@iain-padangsidimpuan.ac.id ${ }^{3}$, \\ nandofahrizal@iain-padangsidimpuan.ac.id ${ }^{4}$
}

\begin{abstract}
ABSTRAK
Return On Asset (ROA) merupakan rasio yang di gunakan untuk mengetahui kemampuan bank dalam menghasilkan keuntungan. Masalah dalam penelitian ini yaitu terjadi fenomena yang tidak sesuai dengan teori. Dimana, pada tahun 2011 triwulan IV Non Performing Financing (NPF) mengalami penurunan yang disertai dengan penurunan nilai Return On Asset (ROA), begitu juga dengan Kualitas Aktiva Produktif (KAP) mengalami kenaikan tetapi tidak diikuti dengan kenaikan Return On Asset (ROA). Penelitian ini merupakan panelitian kuantitatif, dengan lokasi penelitian pada PT. Bank Rakyat Indonesia Syariah, Tbk dengan menggunakan data sekunder sebanyak 40 sampel berupa laporan keuangan konsolidasi triwulan yang diperoleh dari situs www.ojk.go.id. Analisis data yang digunakan adalah uji regresi linier berganda, uji asumsi klasik, uji koefisien determinasi $\left(R^{2}\right)$, serta uji t dan uji F. Hasil penelitian secara parsial (uji t) menunjukkan bahwa Non Performing Financing (NPF) memiliki pengaruh yang signifikan terhadap Return On Asset (ROA), yang dibuktikan dengan $t_{\text {hitung }}>t_{\text {tabel }}$ yaitu $(2.464>2,026)$ dengan taraf signifikansi $0,019<0,05$, dan Kualitas Aktiva Produktif (KAP) memiliki pengaruh yang signifikan terhadap Return On Asset (ROA), yang dibuktikan dengan $-t_{\text {hitung }}<-t_{\text {tabel }}$ yaitu $(-3,385<-2,026)$ dengan taraf signifikansi $0,002<0,05$. Sedangkan secara simultan Non Performing Financing (NPF) dan Kualitas Aktiva Produktif (KAP) berpengaruh secara signifikan terhadap Return On Asset (ROA) yang dibuktikan dengan $F_{\text {hitung }}>F_{\text {tabel }}$ yaitu $(8,981>3,25)$ dengan taraf signifikan 0,001<0,05.

Kata Kunci: NPF, KAP, ROA
\end{abstract}

\section{ABSTRACT}

Return On Assets (ROA) is a ratio used to determine the bank's ability to generate profits. The problem in this research is that there is a phenomenon that is not in accordance with the theory. Where, in 2011 the fourth quarter of Non Performing Financing (NPF) decreased accompanied by a decrease in the value of Return On Assets (ROA), as well as Earning Asset Quality (KAP) increased but was not followed by an increase in Return On Assets (ROA). This research is a quantitative research, with the research location at PT. Bank Rakyat Indonesia Syariah, Tbk using secondary data as many as 40 samples in the form of quarterly consolidated financial statements obtained from the website www.ojk.go.id. Analysis of the data used is multiple linear regression test, classic assumption test, coefficient 
of determination $\left(R^{2}\right)$, as well as $t$ test and $F$ test. The results of the partial study ( $t$ test) show that Non Performing Financing (NPF) has a significant effect on return. On Assets (ROA), as evidenced by $t_{\text {count }}>t_{\text {table }}(2.464>2.026)$ with a significance level of $0.019<0.05$, and Earning Asset Quality (KAP) has a significant effect on Return On Assets (ROA), as evidenced by - $t_{\text {count }}$ $<-t_{\text {table }}$ that is $(-3.385<-2.026)$ with a significance level of $0.002<0.05$. Meanwhile, simultaneously Non-Performing Financing (NPF) and Earning Asset Quality (KAP) have a significant effect on Return On Assets (ROA) as evidenced by $F_{\text {count }}>F_{\text {table }}(8.981>3.25)$ with a significant level of $0.001<0.05$.

Keywords: Knowledge, Interest

\section{A. PENDAHULUAN}

Kehidupan perekonomian didunia sampai saat ini tidak dapat dipisahkan dari dunia perbankan. Dunia perbankan memegang peranan penting dalam stabilitas ekonomi. Bank merupakan tempat untuk melakukan transaksi keuangan masyarakat yang membutuhkannya.

Salah satu bank yang beroperasi dalam sistem syariah adalah PT. Bank Rakyat Indonesia Syariah, Tbk. PT. Bank Rakyat Indonesia Syariah, Tbk adalah salah satu lembaga perbankan besar di Indonesia. PT. Bank Rakyat Indonesia Syariah, Tbk yang berdiri berawal dari akuisi PT. Bank Rakyat Indonesia (Persero), Tbk terhadap Bank Jasa Arta pada 19 Desember 2007 dan setelah mendapatkan izin dari Bank Indonesia pada 16 Oktober 2008 melalui suratnya No. 10/67/KEP.GBI/DpG/2008, maka pada tanggal 17 November 2008 PT. Bank Rakyat Indonesia Syariah, Tbk secara resmi beroperasi.

$$
\text { Salah satu indikator penentu }
$$

Profitabilitas PT. Bank Rakyat Indonesia Syariah, Tbk adalah Return On Asset (ROA) atau sering disebut Return On Investment (ROI). Return On Asset (ROA) adalah rasio yang menunjukkan kemampuan dari keseluruhan asset yang ada digunakan untuk menghasilkan keuntungan. Semakin kecil atau rendah maka rasio ini semakin kurang baik, demikian pula sebaliknya.

Tabel 1

Perkembangan ROA PT. Bank Rakyat Indonesia Syariah, Tbk Periode Maret 2009-Desember

\begin{tabular}{|c|c|c|c|c|}
\hline \multirow{2}{*}{ Tahun } & \multicolumn{4}{|c|}{ Periode } \\
\cline { 2 - 5 } & TW I & TW II & TW III & TW IV \\
\hline 2009 & 3,11 & 2,14 & 1,89 & 0,53 \\
\hline 2010 & 1,12 & 0,97 & 0,24 & 0,33 \\
\hline 2011 & 0,23 & 0,2 & 0,4 & 0,2 \\
\hline 2012 & 0,17 & 1,21 & 1,34 & 1,19 \\
\hline 2013 & 1,71 & 1,41 & 1,36 & 1,15 \\
\hline 2014 & 0,46 & 0,03 & 0,2 & 0,08 \\
\hline 2015 & 0,53 & 0,78 & 0,8 & 0,76 \\
\hline 2016 & 0,99 & 1,03 & 0,98 & 0,95 \\
\hline 2017 & 0,65 & 0,71 & 0,82 & 0,51 \\
\hline 2018 & 0,86 & 0,92 & 0,77 & 0,43 \\
\hline
\end{tabular}

Sumber : Otoritas JasaKeuangan

Melihat kondisi ROA yang berfluktuasi maka akan mempengaruhi kinerja operasional pada periode berikutnya sehingga perlu dikaji faktor yang mempengaruhi perubahan ROA. Yaitu Kualitas Aktiva Produktif. Menurut Lukman Dendawijaya pengertian kualitas aktiva produktif adalah semua aktiva dalam rupiah maupun dalam valuta asing yang dimiliki bank dengan maksud untuk memperoleh penghasilan sesuai dengan fungsinya. 
Tabel 2

Perkembangan KAP PT. Bank Rakyat Indonesia Syariah, Tbk Periode Maret 2009-Desember 2018 (dalam juta)

\begin{tabular}{|c|c|c|c|c|}
\hline \multirow{2}{*}{ Tahun } & \multicolumn{4}{|c|}{ Periode } \\
\cline { 2 - 5 } & TW I & TW II & TW III & TW IV \\
\hline 2009 & 2235011 & 1638934 & 3856807 & 3028581 \\
\hline 2010 & 3705088 & 7048573 & 5680947 & 6431080 \\
\hline 2011 & 6694073 & 12181479 & 11490011 & 10448821 \\
\hline 2012 & 9893770 & 10816428 & 11490011 & 13375716 \\
\hline 2013 & 14329656 & 15519378 & 15781866 & 16370805 \\
\hline 2014 & 19031876 & 17043438 & 17246686 & 19959603 \\
\hline 2015 & 19294636 & 12142695 & 12557443 & 12767307 \\
\hline 2016 & 13176707 & 13557392 & 14026651 & 16947149 \\
\hline 2017 & 16049306 & 18242804 & 18464933 & 20233946 \\
\hline 2018 & 22543081 & 24051474 & 23097544 & 22960374 \\
\hline
\end{tabular}

Sumber: Otoritas Jasa Keuangan

Selain itu penanaman dana yang berpengaruh besar terhadap kemampuan bank dalam mengahasilkan laba adalah pembiayaan. Non Performing Financing (NPF) menurut Faturrahman Djamil pembiayaan bermasalah dalam pembiayaan yang kualitasnya berbeda dalam golongan kurang lancar, diragukan dan macet.

Tabel 3

Perkembangan NPF PT. Bank Rakyat Indonesia Syariah, Tbk Periode Maret 2009-Desember 2018 (dalam \%)

\begin{tabular}{|c|c|c|c|c|}
\hline \multirow{2}{*}{ Tahun } & \multicolumn{4}{|c|}{ Periode } \\
\cline { 2 - 5 } & TW I & TW II & TW III & TW IV \\
\hline 2009 & 8,46 & 6,82 & 4,01 & 3,2 \\
\hline 2010 & 3,47 & 3,39 & 3,37 & 3,19 \\
\hline 2011 & 2,43 & 3,4 & 2,8 & 2,77 \\
\hline 2012 & 3,31 & 2,88 & 2,81 & 3 \\
\hline 2013 & 3,04 & 2,89 & 2,98 & 4,06 \\
\hline 2014 & 4,04 & 4,38 & 4,79 & 4,6 \\
\hline 2015 & 4,96 & 5,31 & 4,9 & 4,86 \\
\hline 2016 & 4,84 & 4,87 & 5,22 & 4,57 \\
\hline 2017 & 4,71 & 4,82 & 4,82 & 6,42 \\
\hline 2018 & 4,92 & 5,13 & 5,3 & 6,73 \\
\hline
\end{tabular}

Sumber: Otoritas Jasa Keuangan

Berdasarkan data diatas maka peneliti menemukan masalah yang terjadi pada tahun 2009 sampai 2018 dimana terdapat ketidaksesuaian antara teori dengan praktek perkembangan Non Performing Financing (NPF) dan Kualitas Aktiva Produktif terhadap Return On Asset (ROA) yang terjadi pada laporan keuangan PT. Bank Rakyat
Indonesia Syariah Tbk yang ditunjukkan dengan terjadinya penurunan NPF pada tahun 2011 triwulan IV yang disertai dengan penurunan nilai ROA pada tahun 2011 triwulan IV ini menunjukkan ketidaksesuaian antara teori dengan praktek. Dimana ketika NPF menurun maka ROA akan meningkat.

Selanjutnya ditunjukkan dengan terjadinya peningkatan KAP pada tahun 2011 pada triwulan IV yang disertai dengan penurunan nilai ROA pada tahun 2011 triwulan IV ini menunjukkan ketidaksesuaian antara teori dengan praktek. Dimana ketika KAP meningkat maka ROA juga akan meningkat. Berdasarkan permasalahan diatas, peneliti tertarik untuk melakukan penelitian dengan judul "Pengaruh Non Performing Financing (NPF) Dan Kualitas Aktiva Produktif (KAP) Terhadap Return On Asset (ROA) Pada PT. Bank Rakyat Indonesia Syariah, Tbk Tahun 2009-2018".

\section{B. METODE}

Tempat pelaksanaan penelitian ini dilakukan di PT. Bank Rakyat Indonesia Syariah, Tbk. Penelitian ini akan dilakukan mulaiDesember 2018 sampai September 2019. Namun hanya mengambil data publikasi PT. Bank Rakyat Indonesia Syariah, Tbk melalui website resmi Otoritas JasaKeuangan (www.ojk.go.id).

Jenis penelitian yang akan dilakukan adalah penelitian kuantitatif. Penelitian kuantitatif merupakan metode untuk menguji teori-teori tertentu dengan cara meneliti hubungan antar variabel. Penelitian ini menggunakan pendekatan kuantitatif berdasarkan runtut waktu (time series).

Dalam penelitian ini populasi yang dimaksud adalah seluruh laporan keuangan tentang NPF, KAP dan ROA PT. Bank Rakyat Indonesia Syariah, Tbk dari tahun 2009-2018 yang berjumlah 40 triwulan pada 
Nurhaliza ${ }^{1}$, Nofinawati ${ }^{2}$, Damri Batubara ${ }^{3}$, Nando Fahrizal ${ }^{4}$

PT. Bank Rakyat Indonesia Syariah, Tbk. Teknik pengambilan sampel yang dilakukan adalah non purposive sampling yaitu sampel jenuh. Sampel jenuh adalah teknik pengambilan sampel bila semua anggota populasinya digunakan sebagai sampel.

Dalam penelitian ini jumlah populasinya kurang dari 100, maka peneliti mengambil semua populasi laporan keuangan triwulan pada PT. Bank Rakyat Indonesia Syariah, Tbk yang berjumlah 40 sampel selama tahun 2009-2018. Teknik pengumpulan data berkaitan dengan mekanisme yang harus dilakukan oleh peneliti dalam mengumpulkan data, yang merupakan langkah paling strategis dalam penelitian, karena tujuan utama penelitian adalah mendapatkan data. Teknik pengumpulan data yang dilakukan pada penelitian ini adalah:

1. Dokumentasi

Dokumentasi adalah teknik pengumpulan data dengan mengumpulkan data berupa datadata tertulis yang mengandung keterangan dan penjelasan serta pemikiran tentang fenomena yang masih aktual dan sesuai dengan masalah penelitian. Adapun data dokumentasi sebagai data pendukung yang bersumber dari data sekunder berdasarkan laporan keuangan PT. Bank Rakyat Indonesia, Tbk yang dipublikasikan dalam website Otoritas Jasa Keuangan (OJK) yaitu www.ojk.go.id.

2. Studi Kepustakaan

Studi kepustakaan yang digunakan dalam penelitian ini adalah sumber buku-buku, jurnal maupun skripsi yang terkait dengan variabel penelitian.

Pengolahan data digunakan melalui program SPSS (Statistical Package For The Social Sciences), dianalisis menggunakan uji asumsi klasik, uji regresi
POINT Vol. 2, No. 1, Jul 2021

linear berganda, dan uji hipotesis. Bentuk persamaan regresi linear berganda adalah:

$$
Y=a+b 1 X 1+b 2 \times 2+e
$$

Keterangan:

Y : : Return On Asset (ROA)

a : Konstanta

b1b2 : Koefisienregresi

X1 : Non Performing Financing(NPF)

X2 : Kualitas Aktiva Produktif (KAP)

e $\quad$ : Error term

\section{HASIL DAN PEMBAHASAN}

Pengambilan data pada penelitian ini yaitu Sumber data yang digunakan adalah data sekunder. Dimana data sekunder adalah data yang bersumber dari catatan, buku, dan majalah berupa laporan keuangan publikasi perusahaan, laporan pemerintah, artikel, buku-buku sebagai teori, majalah, dan lain sebagainya.

Uji Asumsi Klasik

Hasil Uji Multikoliniearitas

\section{Coefficients $^{a}$}

\begin{tabular}{|c|r|r|}
\hline \multirow{2}{*}{ Model } & \multicolumn{2}{|c|}{ Collinearity Statistics } \\
\cline { 2 - 3 } (Constant) & Tolerance & \multicolumn{2}{|c|}{ VIF } \\
\hline NPF & .999 & \\
KAP & .999 & 1.001 \\
& & 1.001 \\
\hline
\end{tabular}

a. Dependent Variable: ROA 
Hasil Uji Heteroskedastisitas

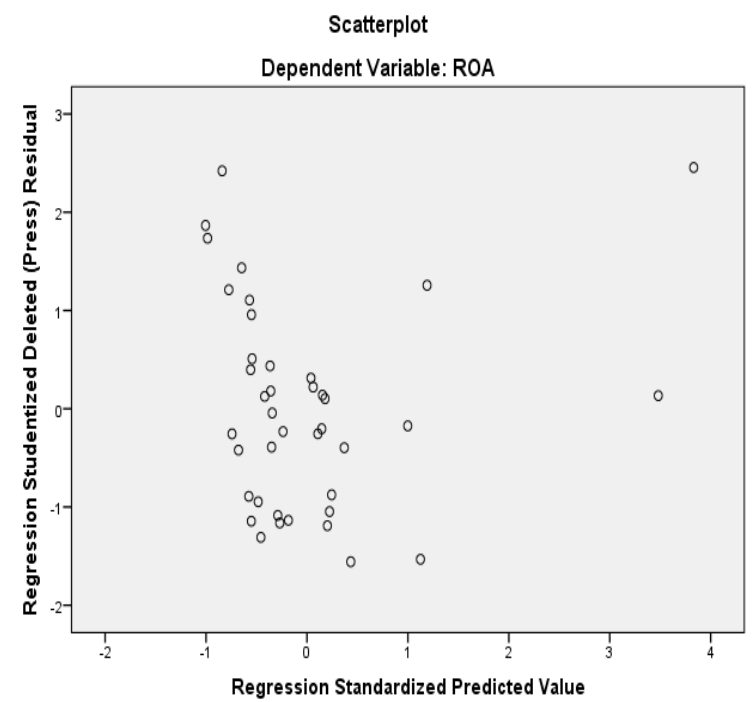

Hasil Uji Autokorelasi

Model Summaryb

\begin{tabular}{|c|r|r|r|r|r}
\hline $\begin{array}{c}\text { Mod } \\
\mathrm{el}\end{array}$ & $\mathrm{R}$ & $\mathrm{R}$ Square & $\begin{array}{c}\text { Square } \\
\text { Squsted R }\end{array}$ & $\begin{array}{l}\text { Std. Error of } \\
\text { the Estimate }\end{array}$ \\
\hline 1 & $.572^{\mathrm{a}}$ & .327 & .290 & .52012 \\
\hline
\end{tabular}

a. Predictors: (Constant), KAP, NPF

b. Dependent Variable: ROA

Analisis Regresi Liniar Berganda

Tabel Regresi Linier Berganda

Coefficientsa

\begin{tabular}{|c|r|r|r|c|c|}
\hline & \multicolumn{2}{|c|}{$\begin{array}{c}\text { Unstandardized } \\
\text { Coefficients }\end{array}$} & $\begin{array}{c}\text { Standardized } \\
\text { Coefficients }\end{array}$ & & \\
\cline { 2 - 4 } Model & \multicolumn{1}{c|}{$\mathrm{B}$} & Std. Error & \multicolumn{1}{|c|}{ Beta } & \multicolumn{1}{c|}{$\mathrm{t}$} & Sig. \\
\hline $\begin{array}{c}\text { (Const } \\
\text { ant) }\end{array}$ & 7.170 & 2.092 & & 3.427 & .002 \\
NPF & .157 & .064 & .332 & 2.464 & .019 \\
KAP & -.991 & .293 & -.457 & -3.385 & .002 \\
\hline
\end{tabular}

a. Dependent Variable: ROA
Berdasarkan hasil pengukuran regresi yang ditunjukkan pada tabel diatas, maka persamaan regresi yang terbentuk adalah:

$Y=a+b 1 X 1+b 2 X 2+e$

Atau

$R O A=a+b 1 N P F+b 2 K A P+e$

ROA $=7,170+0,157$ NPF - 0,991 KAP

Koefisien Determinasi (R2)

Koefisien Determinasi (R2)

\begin{tabular}{|c|c|r|r|r|}
\multicolumn{5}{c|}{ Model Summaryb } \\
\hline $\begin{array}{c}\text { Mod } \\
\mathrm{el}\end{array}$ & $\mathrm{R}$ & $\begin{array}{c}\mathrm{R} \\
\text { Square }\end{array}$ & $\begin{array}{c}\text { Adjusted } \\
\text { R Square }\end{array}$ & $\begin{array}{c}\text { Std. Error of } \\
\text { the Estimate }\end{array}$ \\
\hline 1 & $.572 \mathrm{a}$ & .327 & .290 & .52012 \\
\hline
\end{tabular}

Berdasarkan tabel di atas dapat diketahui Dabahw nilai $R$ Square sebesar 0,327 atau sama dengan 32,7\%. Artinya bahwa NPF dan KAP mampu Aatsomidlaskan variabel dependen (ROA) sebesar 3.803\%. Sedangkan sisanya 67,3\% (100\% - 67,3\%) dijelaskan oleh variabel lain yang tidak dimasukkan dalam penelitian ini.

Uji t (Parsial)

Uji Signifikansi Parsial (Uji t)

a. Predictors:

\begin{tabular}{|r|r|r|r|r|r|}
\hline & \multicolumn{1}{|c|}{ Coefficientsa } \\
& \multicolumn{1}{|c|}{$\begin{array}{c}\text { Unstandardized } \\
\text { Coefficients }\end{array}$} & $\begin{array}{r}\text { Standardized } \\
\text { Coefficients }\end{array}$ & & \\
\cline { 2 - 4 } Model & \multicolumn{1}{|c|}{ B } & Std. Error & Beta & T & Sig. \\
\hline 1 (Constant) & 7.170 & 2.092 & & 3.427 & .002 \\
NPF & .157 & .064 & .332 & 2.464 & .019 \\
KAP & -.991 & .293 & -.457 & -3.385 & .002 \\
\hline
\end{tabular}

a. Dependent Variable: ROA

Berdasarkan tabel diatas, pengujian signifikansi pengaruh variabel independen secara parsial terhadap variabel dependen menggunakan uji t diketahui bahwa $t_{\text {hitung }}(N P F)=2.464, t_{\text {hitung }}(K A P)$ 
$=-3,385$. Untuk mencari $t_{\text {tabel }}$ tersebut diuji pada taraf signifikan $0,05 / 2=0,025$ dengan derajat kebebasan df = n-k-1 atau 40-2-1 = 37 jadi dapat tabel distribusi t pada ttabel $=2,026$. Maka hasil pengujian secara parsial sebagai berikut:

1. Pada variabel NPF memiliki thitung sebesar 2.464 dan ttabel sebesar 2,026. Hasil analisis uji t menunjukkan bahwa variabel NPF memiliki $t_{\text {hitung }}>t_{\text {tabel }}(2.464>2,026)$ dengan taraf signifikansi 0,019<0,05, maka Ha1 diterima. Jadi, dapat disimpulkan bahwa secara parsial variabel NPF memiliki pengaruh dan signifikan terhadap variabel ROA pada PT. Bank Rakyat Indonesia Syariah, Tbk tahun 2009-2018.

2. Pada variabel KAP memiliki $t_{\text {hitung }}$ sebesar -3.385 dan $t_{\text {tabel }}$ sebesar -2,026. Hasil analisis uji $t$ menunjukkan bahwa variabel NPF memiliki pengaruh Jika $-t_{\text {hitung }}<-t_{\text {tabel }} \quad(-3.385<-2.464)$ dengan taraf signifikansi 0,002 <0,05, maka Ha2 diterima. Jadi, dapat disimpulkan bahwa secara parsial variabel KAP memiliki pengaruh dan signifikan terhadap variabel ROA pada PT. Bank Rakyat Indonesia Syariah.

Uji F (Simultan)

Uji Signifikansi Simultan (Uji F)

\begin{tabular}{|c|c|c|c|c|c|}
\hline \multicolumn{6}{|c|}{ ANOVAa } \\
\hline Model & $\begin{array}{l}\text { Sum of } \\
\text { Squares }\end{array}$ & Df & $\begin{array}{l}\text { Mean } \\
\text { Square }\end{array}$ & $\mathrm{F}$ & Sig. \\
\hline Regression & 4.859 & 2 & 2.429 & 8.981 & $.001 b$ \\
\hline Residual & 10.009 & 37 & .271 & & \\
\hline Total & 14.868 & 39 & & & \\
\hline
\end{tabular}

a. Dependent Variable: ROA

b. Predictors: (Constant), KAP, NPF

Berdasarkan pada tabel diatas dapat disimpulkan bahwa nilai $F_{\text {hitung }}$ NPF dan KAP sebesar 8,981 sedangkan nilai Ftabelsebesar
3,25. Tabel distribusi $F$ dicari dengan $d f=n-k-1$ atau 40-2-1 = 37. Hasil analisis data menunjukkan bahwa $F_{\text {hitung }}>F_{\text {tabel }}(8,981>3,25)$, maka Ha diterima artinya bahwa NPF dan KAP secara bersama-sama berpengaruh terhadap variabel ROA. Kesimpulan ini juga diperkuat dengan melihat signifikansi dari tabel diatas bahwa tingkat signifikansi sebesar 0,001 sehingga nilai sig $<0,05(0,001<0,05)$.

Jadi dapat disimpulkan bahwa secara bersama-sama variabel NPF dan KAP memiliki pengaruh secara simultan dan signifikan terhadap variabel ROA pada PT. Bank Rakyat Indonesia Syariah, Tbk tahun 2009-2018.

Berdasarkan hasil analisis regresi yang dilakukan pada penelitian ini diperoleh persamaan regresi yaitu

$R O A=a+b 1 N P F+b 2 K A P+e$

$\mathrm{ROA}=7,170+0,157 \mathrm{NPF}-0,991 \mathrm{KAP}$

Berdasarkan persamaan regresi di atas dapat dijelaskan bahwa:

Nilai konstanta sebesar 7,170 menunjukkan bahwa jika NPF dan KAP diasumsikan nilainya 0 maka ROA nya sebesar 7,170 persen.

Nilai koefisien NPF sebesar 0,157 persen menunjukkan bahwa apabila NPF meningkat sebesar satu persen maka ROA akan mengalami peningkatan sebesar 0,157 persen dengan asumsi nilai variabel lain konstan.

Nilai koefisien KAP sebesar Rp. 0,991 menunjukkan bahwa apabila KAP meningkat sebesar satu persen maka ROA akan mengalami 
penurunan sebesar Rp. 0,991 dengan asumsi nilai variabel lain konstan.

\section{PENUTUP}

\section{Kesimpulan}

Berdasarkan hasil pengolahan data dari penelitian yang berjudul "Pengaruh Non Performing Financing (NPF) dan Kualitas Aktiva Produktif (KAP) Terhadap Return On Asset (ROA) Pada PT. Bank Rakyat Indonesia Syariah, TbkTahun 2009-2018" didapat kesimpulan sebagai berikut:

Ada pengaruh Non Performing Financing (NPF) terhadap Return On Asset (ROA) Pada PT. Bank Rakyat Indonesia Syariah, Tbk. Hal ini dibuktikan dari nilai thitung NPF senilai $2.464>$ ttabel 2,026.

Ada Pengaruh Kualitas Aktiva Produktif (KAP) Terhadap Return On Asset (ROA) Pada PT. Bank Rakyat Indonesia Syariah, Tbk. Hal ini dibuktikan dari nilait hitung KAP senilai $-3,385<$ ttabel $-2,026$.

Secara simultan ada pengaruh Non Performing Financing (NPF) dan Kualitas Aktiva Produktif (KAP) Terhadap Return On Asset (ROA) Pada PT. Bank Rakyat Indonesia Syariah, Tbk. Hal ini dibuktikan dari Fhitung sebesar $8,981>$ Ftabel 3,25.

\section{Saran}

Semoga adanya pengetahuan masyarakat terhadap minat produk perbankan syariah

\section{DAFTAR PUSTAKA}

Abdul Nasser Hasibuan, The Effect of Profitability Ratios on Financial Distress in Islamic Commercial Banks in Indonesia.

Ali Hardana, Analisis Faktor-Faktor Yang Mempengaruhi Pendapatan Industri Kecil Di Kota Padangsidimpuan Dan Kabupaten Tapanuli Selatan.

Lukman Dendawijaya, Manajemen Perbankan, Jakarta: Ghalia Indonesia, 2009.

Faturrahman Djamil, Penyelesaian Pembiayaan Bermasalah di Bank Syariah, Jakarta: PT Gramedia Pustaka Utama, 2012.

Henry Susanto dan Khaerul Umam, Manajemen Pemasaran Bank Syariah, Bandung: Pustaka Setia, 2013.

Kasmir, Analisis Laporan Keuangan, Jakarta: PT. Raja Grafindo Persada, 2012.

Lemiyana, Erdah Litriani, "Pengaruh NPF, FDR, BOPO Terhadap Return On Asset (ROA) Pada Bank Umum Syariah", dalam Jurnal I-Economic Vol. 2. No.1 Juli 2016, hlm. 34.

Nofinawati, Persepsi Pedagang Pasar Inpres Sadabuan Terhadap Baitul Mal Wat Tamwil (BMT) Insani Padangsidimpuan

Sugiono, MetodologiPenelitianKuantitatif, Kualitatifdan R \& D, Jakarta: Alfabet, 2013.

TajulArifin, MetodePenelitianEkonomi Islam Muamalah, Bandung: CV PustakaSetia, 2014.

Wiratna Sujarweni, Metodologi Penelitian Bisnis dan Ekonomi, Jakarta: Pustaka Baru Perss, 